Kumawula, Vol. 3, No.2, Agustus 2020, Hal 204 - 215

DOI: https://doi.org/10.24198/kumawula.v3i2.26436

ISSN 2620-844X (online)

Tersedia online di http://jurnal.unpad.ac.id/kumawula/index

\title{
PEMBERDAYAAN MASYARAKAT MELALUI PEMANFAATAN PEKARANGAN SEBAGAI WARUNG HIDUP KELUARGA DI DESA KUTAMANDIRI KECAMATAN TANJUNGSARI
}

\author{
Ratnia Solihah \\ Departemen Ilmu Politik, Fakultas Ilmu Sosial dan Ilmu Politik, Universitas Padjadjaran \\ ratnia@unpad.ac.id
}

\begin{abstract}
ABSTRAK
Fokus tulisan ini adalah pemberdayaan masyarakat melalui pemanfaatan pekarangan sebagai warung hidup keluarga, sebagai upaya menindaklanjuti hasil survey pemetaan profil, masalah dan potensi Desa Kutamandiri Kecamatan Tanjungsari Kabupaten Sumedang. Metode yang digunakan dalam tulisan ini adalah metode kualitatif, dengan teknik pengambilan data berdasarkan studi literatur dan studi lapangan. Studi lapangan dilakukan melalui survey pemetaan profil, masalah dan potensi Desa Kutamandiri, observasi partisipan, melakukan design thinking, dan menyelenggarakan pemberdayaan masyarakat melalui pemanfaatan pekarangan sebagai warung hidup keluarga dengan berbagai kegiatan yang melibatkan Tim PPM, Tim KKN, Penyuluh pertanian, Ibu-ibu PKK dan ibu-ibu Kelompok Wanita Tani (KWT) Desa Kutamandiri. Pemberdayaan masyarakat ini dilakukan melalui kegiatan sosialisasi atau penyuluhan tentang pentingnya pemanfaatan pekarangan sebagai warung hidup keluarga; pelatihan pemanfaatan pekarangan sebagai warung hidup keluarga, pemberian benih tanaman warung hidup bagi warga Desa Kutamandiri (melalui ibu-ibu rumah tangga), serta evaluasi dan monitoring kegiatan pemanfaatan, penanaman dan pemeliharaan tanaman warung hidup dalam memenuhi kebutuhan keluarga Secara keseluruhan kegiatan pemberdayaan ekonomi masyarakat tersebut dapat dilakukan dengan baik, walaupun terdapat beberapa kendala. Kendala tersebut diatasi dengan upaya yang dilakukan oleh Tim PPM maupun pihak-pihak terkait lainnya.
\end{abstract}

Kata Kunci: pemberdayaan; masyarakat; pemanfaatan; pekarangan; warung hidup

\begin{abstract}
The focus of this paper is community empowerment through the use of the yard as a stall for family life, as an effort to follow up the survey results mapping the profile, problems and potential of Kutamandiri Village, Tanjungsari District, Sumedang Regency.. The method used in this paper is a qualitative method, with data collection techniques based on literature studies and field studies. Field studies were carried out through survey mapping of profiles, problems and potentials of Kutamandiri Village, participant observation, design thinking, and organizing community empowerment through the use of the yard as a family life stall with various activities involving the PPM Team, KKN Team, Agricultural Extension Team, PKK Women and the women of the Peasant Women's Group (KWT) of Kutamandiri Village. This community empowerment is done through socialization activities or counseling about the importance of using the yard as a family stall; training in the use of the yard as a family life stall, provision of live stall plant seeds for the residents of Kutamandiri Village (through housewives), as well as evaluation and monitoring of the utilization, planting and maintenance of
\end{abstract}


living stalls in meeting the family's needs Overall the economic empowerment activities of the community can be done well, although there are some obstacles. These constraints were overcome by efforts made by the PPM Team and other relevant parties.

Keywords: empowerment, community, utilization, yard, food stalls

\section{PENDAHULUAN}

Pemberdayaan masyarakat merupakan upaya yang dilakukan oleh masyarakat, dengan atau tanpa dukungan dari pihak luar, untuk memperbaiki kehidupannya yang berbasis kepada daya mereka sendiri, melalui upaya optimasi daya serta peningkatan posisi tawar yang dimiliki, dengan perkataan lain, pemberdayaan harus menempatkan kekuatan masyarakat sebagai modal utama serta menghindari "rekayasa" pihak luar yang seringkali mematikan kemandirian masyarakat setempat.

Beberapa kegiatan pemberdayaan masyarakat yang bertujuan untuk meningkatkan kemandirian dan kesejahteraan masyarakat dilakukan dalam bentuk program pemberdayaan masyarakat baik yang dilakukan oleh kelompok masyarakat yang difasilitasi pemerintah setempat, yang dilakukan melalui kolaborasi berbagai pihak terkait (stakeholders), maupun yang difasilitasi oleh Tim akademisi. Beberapa program pemberdayaan masyarakat dalam upaya meningkatkan jiwa dan potensi kewirausahaan masyarakat dilakukan oleh Tim akademisi (Tim PPM Unpad) yang terintegrasi dengan kegiatan KKN tematik kewirausahaan, antara lain sebagaimana dijelaskan dalam tulisannya Nina Karlina dkk yang berjudul Pemberdayaan Jiwa Kewirausahaan Masyarakat Desa Cisempur dan Pendampingan Kewirausahaan berbasis E-Commerce (2019) dan dalam tulisannya Ahmad Buchari dkk yang berjudul "Pengembangan Potensi Kewirausahaan Di Desa Cikeruh melalui Program “Cikeruhpreneur” dan Produk Unggulan "Pa'Engsit” (2019), serta beberapa bentuk pemberdayaan masyarakat lainnya yang terkait dengan pemberdayaan masyarakat melalui kewirausahaan sosial yang melibatkan para pelaku UMKM secara langsung.

Namun tidak seluruh program pemberdayaan masyarakat dalam upaya meningkatkan ekonomi masyarakat itu terkait dengan pelaku usaha (UMKM), karena pemberdayaan ekonomi masyarakat juga dapat dilakukan bagi masyarakat di luar pelaku UMKM, baik secara individu maupun kelompok usaha. Salah satu program pemberdayaan masyarakat tersebut adalah melalui pemanfaatan pekarangan sebagai warung hidup keluarga.

Saat ini, keberadaan pekarangan sudah mulai terdesak fungsinya seiring dengan pertambahan jumlah penduduk, sehingga banyak lahan pekarangan yang dijadikan ruangan tertutup sebagai 
bagian dari rumah warga. Selain itu, pekarangan yang ada pun banyak yang terbengkalai dan dibiarkan tanpa dimanfaatkan oleh pemiliknya padahal pekarangan mempunyai manfaat yang sangat besar. Pekarangan bukan hanya bermanfaat secara ekologis, tetapi juga mempunyai peranan yang cukup penting dari sisi ekonomi.

Pekarangan dapat berfungsi sebagai lumbung hidup (warung hidup), baik lumbung pangan maupun lumbung gizi dan sebagai apotik hidup (Madyowati, 2017). Fungsi dasar pekarangan secara sosial ekonomis, yaitu produksi secara subsisten, dimana pekarangan dapat menghasilkan produksi untuk komersiil dan memberi tambahan pendapatan keluarga terutama di daerah yang mempunyai akses pasar yang baik. Produk pekarangan tersebut antara lain buah-buahan serta sayuran (Arifin, 2013). Pemanfaatan tanah pekarangan juga dapat dilihat dari kompleksitas tanamannya dan komoditas yang dihasilkan. Kompleksitas dan banyak produksi tersebut tergantung dari keanekaragaman usaha dan kombinasi usaha dari masyarakat. Usaha dari pemanfaatan tanah pekarangan dapat memberikan sumbangan ratarata $49 \%$ dari pendapatan rumah tangga. Besar kecilnya kontribuasi pekarangan terhadap pendapatan keluarga tergantung pada luas dan tingkat pemanfaatan tanah pekarangan tersebut (Ginting, 1994). Dengan demikian, pemanfaatan pekarangan merupakan salah satu alternatif sumber daya yang dapat digunakan untuk pemenuhan kebutuhan pangan atau warung hidup keluarga.

Desa Kutamandiri merupakan salah satu desa yang terdapat di Kecamatan Tanjungsari Kabupaten Sumedang Provinsi Jawa Barat. Desa Kutamandiri terdiri dari 4 Dusun, 15 RW dan 43 RT dengan jumlah penduduk 10.551 pada tahun 2018. Wilayah Desa Kutamandiri terdiri dari Lahan Pemukiman, Pertanian dan Peternakan. Masyarakat yang ada di Desa Kutamandiri secara garis besar berprofesi sebagai petani, peternak, pengrajin benang gelasan, produsen makanan (Borang KKN Kewirausahaan 2019).

Masyarakat Desa Kutamandiri pada umumnya memiliki lahan pekarangan yang belum dimanfaatkan secara optimal. Padahal pemanfaatan pekarangan di pedesaan mempunyai banyak keuntungan terutama dalam meningkatan pendapatan keluarga misalnya sebagai warung hidup. Upaya untuk memanfaatkan pekarangan sebagai warung merupakan salah satu pilihan yang sangat tepat dalam menunjang kebutuhan ekonomi keluarga. Apalagi pemerintah Desa Kutamandiri sejak tahun 2018 sangat gencar menghimbau seluruh masyarakat untuk memanfaatan pekarangan rumahnya sebagai warung hidup keluarga (Hasil survei pemetaan dan potensi KKN Kewirausahaan 2020). 
Program pemanfaatan pekarangan rumah yang dicanangkan dan direncanakan oleh Permerintah Desa Kutamandiri tahun 2019, dalam implementasintya belum berjalan dengan baik, padahal pemerintah Desa sudah berkali-kali mengajak warganya untuk memanfaatkan pekarangan rumah dengan menanami warung hidup atau apotik hidup untuk dapat memenuhi keperluan sehari-hari bagi warganya, atau dapat membantu ekonomi keluarganya.

Untuk itu, dalam PPM kewirausahaan ini penulis berupaya meneruskan rencana program pemerintah Desa Kutamandiri tersebut yang melibatkan warga Desa, khususnya ibu-ibu rumah tangga (melalui keterlibatan ibu-ibu PKK dan ibu-ibu KWT) dalam memanfaatkan pekarangan rumahnya untuk menunjang dan memenuhi keperluan sehari-hari. Bentuk kegiatan yang akan dilakukan adalah "Pemberdayaan Masyarakat melalui Pemanfaatan Pekarangan sebagai Warung Hidup Keluarga di di Desa Kutamandiri Kecamatan Tanjungsari Kabupaten Sumedang”.

Pemberdayaan masyarakat ini melibatkan ibu-ibu rumah tangga dalam memanfaatkan pekarangan rumahnya sebagai warung hidup keluarga. Ibu-ibu rumah tangga pada umumnya tidak bekerja, mereka hanya beraktifitas sebagai ibu rumah tangga. Hal ini menyebabkan mereka memiliki waktu luang yang cukup banyak setelah melakukan tugas rutin sebagai ibu rumah tangga. Salah satunya dalam ikut membantu ekonomi keluarganya, dengan memanfaatkan pekarangan rumahnya sebagai warung hidup keluarga.

Adapun tujuan dari kegiatan ini adalah:

a. Memberikan edukasi melalui aspek kognitif, afektif dan psikomotorik bagi warga tentang pentingnya pemanfaatan pekarangan sebagai warung hidup keluarga.

b. Memfasilitasi terlaksananya program pemerintah Desa Kutamandiri Kecamatan Tanjungsari Kabupaten Sumedang dalam upaya memberdayakan masyarakat melalui pemanfaatan pekarangan sebagai warung hidup yang dapat menopang kebutuhan seharihari warganya.

c. Menumbuhkan nilai-nilai entrepreneurship (kewirausahaan) bagi warga desa melalui ibuibu rumah tangga umumnya, dan khususnya Tim PKK RT, RW dan Desa Kutamandiri dalam membantu dan memenuhi kebutuhan ekonomi keluarga.

\section{METODE}

Dalam tulisan ini, digunakan metode kualitatif, dimana dalam memperoleh data digunakan studi literatur terkait pemberdayaan masyarakat melalui pemanfaaatan pekarangan dan 
digunakan studi lapangan. Studi lapangan dilakukan dengan melakukan survey pemetaan masalah dan potensi, observasi partisipan, melakukan design thinking dan melaksanakan kegiatan pemberdayaan masyarakat melalui pemanfaaatan pekarangan sebagai warung hidup keluarga.

Pemberdayaan Masyarakat melalui Pemanfaatan Pekarangan sebagai Warung Hidup Keluarga di Desa Kutamandiri Kecamatan Tanjungsari Kabupaten Sumedang, dilakukan melalui metode:

a. Sosialisasi atau Penyuluhan tentang pentingnya pemanfaatan pekarangan sebagai warung hidup keluarga.

b. Pelatihan pemanfaatan pekarangan sebagai Warung Hidup Keluarga

c. Pemberian benih tanaman warung hidup bagi warga Desa Kutamandiri (melalui ibu-ibu rumah tangga)

d. Evaluasi dan Monitoring kegiatan pemanfaatan, penanaman dan pemeliharaan tanaman warung hidup dalam memenuhi kebutuhan keluarga.

Sasaran dari kegiatan ini adalah ibu-ibu rumah tangga di Desa Kutamandiri. Namun sehubungan keterbatasan fasilitas pelatihan, biaya dan tenaga instruktur, maka dalam kegiatan pemberdayaan masyarakat melalui pemanfaatan pekarangan rumah sebagai warung hidup keluarga ini melibatkan 50 peserta kegiatan sosialisasi dan pelatihan yang diwakili oleh Tim PKK RT, Tim PKK RW dan Tim PKK Desa Kutamandiri.

\section{HASIL DAN PEMBAHASAN}

Pemberdayaan adalah proses meningkatkan kapasitas individu atau kelompok untuk membuat pilihan atau mengubah pilihan tersebut menjadi tindakan atau hasil yang ingin dicapai (World Bank, 2011). Hal tersebut senada dengan pendapat Kuswandoro (2016), bahwa pemberdayaan adalah suatu proses individual dan sosial, yakni suatu penguatan kemampuan individual, peningkatan kompetensi, penumbuh kembangan kreativitas. Ketiganya memerlukan kebersamaan yang memperkenankan warga desa mengembangkan perasaan bersama yang menjadi tanggung jawabnya secara mandiri atas dasar kebutuhan.

Keterlibatan masyarakat yang diberdayakan sangatlah penting sehingga tujuan dari pemberdayaan dapat tercapai secara maksimal. Program yang mengikut sertakan masyarakat, memiliki beberapa tujuan yaitu agar bantuan tersebut efektif sesuai dengan kehendak dan mengenali kemampuan serta kebutuhan mereka, serta meningkatkan keberdayaan 
(empowering) masyarakat dengan pengalaman merancang, melaksanakan dan mempertanggungjawabkan upaya peningkatan diri dan ekonomi.

Salah satu bentuk pemberdayaan masyarakat adalah melalui pemanfaatan pekarangan sebagai warung hidup keluarga. Pekarangan adalah sebidang tanah di sekitar rumah yang mudah di usahakan dengan tujuan untuk meningkatkan pemenuhan gizi mikro melalui perbaikan menu keluarga. Pekarangan sering juga disebut sebagai lumbung hidup, warung hidup atau apotik hidup. Dalam kondisi tertentu, pekarangan dapat memanfaatkan kebun di sekitar rumah.

Terkait dengan hal tersebut, beberapa fungsi ekosistem pekarangan adalah sebagai berikut:

1. Fungsi Lumbung Hidup

Untuk menghadapi musim paceklik, pekarangan biasanya dapat membantu penghuninya menyediakan sumber pangan yang hidup (lumbung hidup) seperti : tanaman palawija, tanaman pangan dan hortikultura, hasil binatang peliharaan, dan ikan

\section{Fungsi Warung Hidup}

Pekarangan menyediakan berbagai jenis tanaman dan binatang peliharaan yang setiap saat siap dijual untuk kebutuhan keluarga pemiliknya.

\section{Fungsi Apotik Hidup}

Pekarangan menyediakan berbagai jenis tanaman obat-obatan, misalnya sembung, jeruk nipis, kunir, kencur, jahe, kapulaga dan sebagainya. Tanaman tersebut dapat digunakan untuk obat-obatan tradisional yang tidak kalah khasiatnya dengan obat-obatan yang diproduksi secara kimiawi.

\section{Fungsi Sosial}

Lahan pekarangan yang letaknya berbatasan dengan tetangga biasanya digunakan untuk ngumpul-ngumpul hajatan, tempat bermain, berdiskusi, dan kegiatan social lainnya. Hasil pekarangan biasanya saling ditukarkan dengan hasil pekarangan tetangga untuk menjalin keeratan hubungan sosial.

5. Fungsi Sumber Benih dan Bibit.

Pekarangan yang ditamani berbagai jenis tanaman dan untuk memelihara ternak atau ikan mampu menyediakan benih atapun bibit baik berupa biji-bijian, stek, cangkok, okulasi maupun bibit ternak dan benih ikan.

\section{Fungsi Pemberian Keasrian}

Pekarangan yang berisi berbagai jenis tanaman, baik tanaman merambat, tanaman perdu maupun tanaman tinggi dan besar, dapat menciptakan suasana asri dan sejuk. 


\section{Fungsi Pemberi Keindahan}

Pekarangan yang ditanami dengan berbagai jenis tanaman bunga-bungaan dan pagar hidup yang ditata rapi akan memberi keindahan dan ketenangan bagi penghuninya.

(http://bpptiris.blogspot.com/2012/08/pemanfataan-pekarangan-sebagai-lumbung.html)

Berdasarkan uraian tersebut, lahan pekarangan yang dikelola secara optimal dapat memberikan manfaat bagi rumah tangga atau keluarga yang mengelolanya. Lahan pekarangan yang dikelola dengan baik dapat memberikan manfaat antara lain adanya peningkatan gizi keluarga, tambahan pendapatan keluarga, lingkungan rumah asri, teratur, indah dan nyaman.

Pemberdayaan masyarakat melalui pemanfaatan pekarangan merupakan salah bentuk program PPM yang didasarkan pada hasil survey pemetaan profil, masalah dan potensi di Desa Kutamandiri. Masyarakat Desa Kutamandiri pada umumnya memiliki lahan pekarangan yang belum dimanfaatkan secara optimal. Padahal pemanfaatan pekarangan di pedesaan mempunyai banyak keuntungan terutama dalam meningkatan pendapatan keluarga misalnya sebagai warung hidup. Upaya untuk memanfaatkan pekarangan sebagai warung merupakan salah satu pilihan yang sangat tepat dalam menunjang kebutuhan ekonomi keluarga. Apalagi pemerintah Desa Kutamandiri sejak tahun 2018 sangat gencar menghimbau seluruh masyarakat untuk memanfaatan pekarangan rumahnya sebagai warung hidup keluarga (Hasil survei pemetaan dan potensi KKN Kewirausahaan 2020).

Dalam program pemberdayaan masyarakat melalui pemanfaatan pekarangan sebagai warung hidup keluarga di Desa Kutamandiri, beberapa kegiatan yang dilakukan oleh Tim PPM adalah sebagai berikut:

\section{a. Sosialisasi dan Penyuluhan tentang pentingnya pemanfaatan pekarangan sebagai warung hidup keluarga; diselenggarakan di Kantor Desa Kutamandiri.}

Kegiatan sosialisasi dilakukan oleh Tim PPM dengan menjelaskan hasil pemetaan potensi dan masalah di Desa Kutamandiri. Dalam sosialisasi ini Tim memaparkan pentingnya pemberdayaan masyarakat melalui pemanfaatan pekarangan sebagai warung hidup keluarga untuk dapat membantu kebutuhan pangan keluarga sehari-hari, sekaligus dapat menjadi alternatif kegiatan usaha kelaurga yang dapat menjadi andalan keluarga bila dikembangkan serius dan secara profesional.

Kegiatan penyuluhan ini dibantu oleh penyuluh pertanian Desa Kutamandiri dari UPT Dians Pertanian Kecamatan Tanjungsari yang kebetulan bertempat tinggal di Desa Kutamandiri, 
serta mengikutsertakan ibu-ibu PKK dan Ibu-ibu KWT Desa Kutamandiri. Hal ini dilakukan agar warga juga dapat mengetahui manfaat pekarangan sebagai warung hidup yang dapat menopang kebutuhan keluarga sehari-hari, terutama untuk memenuhi kebutuhan dapur keluarga.

\section{b. Program pelatihan pemanfaatan pekarangan sebagai Warung Hidup Keluarga; diselenggarakan di Kantor Desa Kutamandiri}

Setelah melakukan sosialisasi dan penyuluhan, selanjutnya Tim PPM dengan dibantu penyuluh pertanian, serta Tim KKN Kewirausahaan Unpad Desa Kutamandiri melakukan uji coba penanaman benih sayuran (pokcoy dan seladah) bersama-sama dengan ibu-ibu KWT dan ibu-ibu PKK Desa Kutamandiri, dengan bertempat di salah satu rumah anggota KWT Desa Kutamandiri yang dapat dijadikan percontohan (demplot warung hidup). Hal ini dilakukan agar warga juga dapat mengetahui cara menanam benih (bibit) secara langsung degan dipandu penyuluh pertanian, juga mengetahui cara pemeliharaannya atau perawatannya dan pengembangbiakannya.

\section{c. Program pemberian benih tanaman warung hidup bagi warga Desa Kutamandiri (melalui ibu-ibu rumah tangga)}

Setelah sosialisasi dan pelatihan pemanfaatan pekarangan sebagai warung hidup keluarga dilaksanakan, selanjutnya tim PPM melakukan program pemberian benih tanaman warung hidup berupa benih (bibit) sayuran pokcoy dan seladah berserta media tanamnya (polybag dan pot) untuk warga Desa Kumandiri, yang diberikan secara simbolis oleh Tim PPM kepada pemerintah Desa melalui Sekretaris Desa Kutamandiri. Selanjutnya Sekretaris Desa menyerahkan ke warga masyarakat melalui 4 orang Kepala Dusun serta ke perwakilan anggota KWT dan perwakilan PKK Desa Kutamandiri. Pemberian benih (bibit) tanaman warung hidup diselenggarakan di Kantor Desa Kutamandiri dengan disaksikan oleh Kepala Desa, Sekretaris Desa dan Staf pemerintah Desa, Ketua BPD, perwakilan PKK, perwakilan KWT, Kepala-kepala Dusun, perwakilan RW dan perwakilan warga desa Kutamandiri.

Selanjutnya benih atau bibit tersebut didistribusikan oleh para kepala dusun ke seluruh Ketua RW yang berada dalam lingkungannya. Kemudian Ketua RW mendistribusikannya ke warga yang layak mendapatkan bantuan benih atau bibit untuk di dimanfaatkan di pekarangan rumahnya dalam upaya menopang kebutuhan ekonomi keluarga. Selain itu, benih (bibit) dan 
media tanaman juga diserahkan ke seluruh anggota KWT dan ibu-ibu PKK Desa Kutamandiri untuk dimanfaatkan sebagai warung hidup keluarga.

\section{d. Evaluasi kegiatan pemanfaatan, penanaman dan pemeliharaan tanaman warung hidup dalam memenuhi kebutuhan keluarga}

Evaluasi kegiatan pemberdayaan masyarakat melalui pemanfaatan pekarangan sebagai warung hidup keluarga dilakukan Tim PPM dengan mengunjungi 5 sampel pekarangan rumah yang ditanami warung hidup di 4 Dusun di lingkungan Desa Kutamandiri. Hal ini dilakukan untuk memastikan bahwa pemberian benih (bibit) dalam upaya memberdayakan masyarakat dilakukan, didistribusikan dan dimanfaatkan oleh warga dengan baik. Dalam kegiatan evaluasi ini, Tim PPM dibantu oleh penyuluh pertanian dan Tim KWT Kutamandiri Harum Manis sebagai kelompok Wanita yang tugas dan fungsinya relevan dengan kegiatan pemberdayaan masyarakat melalui pemanfaatan pekarangan sebagai warung hidup keluarga di lingkungan Desa Kutamandiri.

Secara keseluruhan kegiatan pemberdayaan masyarakat yang dilakukan oleh Tim PPM dapat dilaksanakan dengan baik, berkat bantuan dan kerjasama dengan Penyuluh Pertanian dan Tim KKN UNPAD, serta dukungan dari pemerintah desa, ibu-ibu KWT, ibu-ibu Tim Penggerak PKK, Kepala Dusun dan ketua RW di Desa Kutamandiri.

Beberapa hal yang masih menjadi kendala dan belum optimal dilakukan dalam kegiatan pemberdayaan masyarakat melalui pemanfaatan pekarangan sebagai warung hidup keluarga di lingkungan Desa Kutamandiri adalah:

a. Jumlah warga yang mendapatkan bantuan benih (bibit) belum terjangkau secara luas, hanya beberapa perwakilan warga (15 warga ) dari setiap RW dengan total 15 RW di Desa Kutamandiri.

b. Bibit (benih) yang diberikan belum beragam, karena ketersediaan benih di pelaku usaha tani yang terbatas.

c. Media tanam tidak hanya pot saja tetapi juga polybag, dengan pertimbangan untuk memperbanyak media tanam di setiap pekarangan rumah warga di Desa Kutamandiri serta mempertimbangkan kemampuan biaya, jumlah tenaga SDM dan kepraktisan dalam mendistribuskannya ke warga. 
Solusi dari kendala atau kondisi tersebut adalah:

a. Selain warga di lingkungan RW, bibit (benih) juga diberikan kepala Tim KWT dan ibuibu PKK Desa Kutamandiri yang diberikan pelatihan pemanfaatan pekarangan sebagai warung hidup, untuk selanjutnya diharapkan KWT dan ibu-ibu PKK dapat menjadi fasilitator dalam program pemanfaatan pekarangan selanjutnya ke warga lainnya yang diseselanggarakan secara swadaya dengan dibimbing oleh penyuluh pertanian.

b. Ketersediaan bibit (benih) yang terbatas diatasi dengan jumlah bibit (benih) sayuran pokcoy dan seladah yang setiap harinya sering dipergunakan warga sebagai bahan masakan (dapur keluarga) dan masa panennya tidak lama, sehingga dapat dikembangbiakan dan dirasakan manfaatnya untuk kebutuhan sehari-hari keluarga.

c. Memperbanyak jumlah polybag yang didistribusikan ke warga, agar dapat dimanfaatkan oleh warga dengan praktis oleh banyak warga, dan penggunaannya sesuai dengan kondisi (luas) pekarangan masing-masing warga.

Pemberdayaan masyarakat melalui pemanfaatan pekarangan sebagai warung hidup keluarga membutuhkan peran pihak lainnya sehubungan kegiatan pemberdayaan masyarakat yang dilakukan oleh Tim PPM Unpad belum menjangkau seluruh warga desa sebagai sasarannya. Selain itu keberlanjutan pemanfaatan pekarangan sebagai warung hidup keluarga ini memerlukan pendampingan dan dukungan dari berbagai pihak yang terkait agar dapat menopang ekonomi keluarga dan meningkatkan kesejahteraan warga desa. Untuk itu peran pemerintah desa, akademisi, penyuluh pertanian, Tim KWT, Tim penggerak PKK, stakeholders lainnya dan warga khususnya sangat penting dalam meningkatkan dan memasyarakatkan pemanfaatan pekarangan sebagai warung hidup keluarga, sebagai salah satu upaya untuk menopang atau membantu warga dalam memenuhi kebutuhan sehari-hari keluarga.

\section{SIMPULAN}

Berdasarkan hasil dan pembahasan di atas, dapatlah disimpulkan bahwa pemberdayaan masyarakat melalui pemanfaatan pekarangan sebagai warung hidup keluarga di Desa Kutamandiri Kecamatan Tanjungsari Kabupaten Sumedang, merupakan salah satu bentuk upaya memberdayakan masyarakat yang menindaklanjuti hasil survey dan pemetaan masalah dan potensi Desa Kutamandiri. Pemberdayaan masyarakat melalui pemanfaatan pekarangan sebagai warung hidup keluarga tersebut diselenggarakan dengan melakukan berbagai kegiatan oleh Tim PPM dengan dibantu atau difasilitasi oleh penyuluh pertanian, Tim KKN UNPAD, 
Tim KWT, dan Tim penggerak PKK Desa Kutamandiri dalam pelaksanaannya. Kegiatankegiatan yang dilakukan dalam pemberdayaan ekonomi masyarakat melalui pemanfaatan pekarangan sebagai warung hidup keluarga tersebut meliputi: kegiatan sosialisasi atau penyuluhan tentang pentingnya pemanfaatan pekarangan sebagai warung hidup keluarga; pelatihan pemanfaatan pekarangan sebagai warung hidup keluarga, pemberian benih tanaman warung hidup bagi warga Desa Kutamandiri (melalui ibu-ibu rumah tangga), serta evaluasi dan monitoring kegiatan pemanfaatan, penanaman dan pemeliharaan tanaman warung hidup.

Dengan diberikannya beberapa kegiatan tersebut, keberlanjutan pemberdayaan masyarakat melalui pemanfaatan pekarangan sebagai warung hidup keluarga di Desa Kutamandiri diharapkan:

a. Tim KWT dan Tim Penggerak PKK Desa Kutamandiri dapat meneruskan program pemberdayaan masyarakat melalui pemanfaatan pekarangan sebagai warung hidup keluarga ini menjadi lebih luas sasarannya yang dapat dilakukan secara swadaya oleh masyarakat.

b. Evaluasi dan monitoring program pemberdayaan masyarakat melalui pemanfaatan pekarangan sebagai warung hidup keluarga ini dapat dilakukan tim penyuluh pertanian Desa Kutamandiri dengan dibantu oleh Tim KWT dan Tim Penggerak PKK Desa Kutamandiri. Hal ini untuk mempertahankan keberlangsung program ini serta untuk mengatasi permasalahan terkait pemeliharaannya yang dihadapi oleh warga desa.

c. Kegiatan pemberdayaan masyarakat melalui pemanfaatan pekarangan sebagai warung hidup keluarga ini dapat menumbuhkan nilai-nilai entrepreneurship bagi warga desa melalui ibu-ibu rumah tangga umumnya, dan khususnya Tim PKK RT, RW dan Desa Kutamandiri dalam membantu dan memenuhi kebutuhan ekonomi keluarga.

\section{UCAPAN TERIMA KASIH}

Ucapan terima kasih penulis sampaikan kepada UNPAD yang telah memberikan bantuan dana dalam skema Hibah PPM Kewirausahaan tahun 2020 melalui DPRM UNPAD serta rekanrekan penulis di FISIP Universitas Padjadjaran yang telah menjadi teman diskusi selama penulisan naskah ini.

\section{DAFTAR PUSTAKA}

Arifin, Susilo H. 2013. Pekarangan Kampung untuk Konservasi Agribiodiversitas dalam mendukung keanekaragaman dan ketahanan pangan Indonesia. Bogor: IPB Press. 
Borang KKN Kewirausahaan 2019 di Desa Kutamandiri.

Buchari, Ahmad, dkk. 2019. Pengembangan Potensi Kewirausahaan Di Desa Cikeruh melalui Program “Cikeruhpreneur” dan Produk Unggulan "Pa’Engsit”. Jurnal Kumawula UNPAD, Vol. 2 No. 3., Desember 2019.

Ginting. 1994. Pekarangan petani dan kemiskinan. Yogyakarta: Gadjah Mada University.

Karlina, Nina, dkk. 2019. Pemberdayaan Jiwa Kewirausahaan Masyarakat Desa Cisempur dan Pendampingan Kewirausahaan Berbasis E-Commerce. Jurnal Kumawula UNPAD, Vol. 2 No. 3., Desember 2019.

Madyowati, S.O, 2017. Sosialisasi Pengisian Buku Catatan Pemanfaatan Pekarangan/Hatinya PKK (Peternakan, Perikanan, Warung Hidup, Lumbung Hidup, TOGA, Tanaman Keras. Surabaya: Universitas Dr Sutomo.

http://bpptiris.blogspot.com/2012/08/pemanfataan-pekarangan-sebagai-lumbung.html

Kuswandoro, W. E. 2016. Strategi Pemberdayaan Masyarakat Desa Berbasis Partisipasi. (https:// www.researchgate.net/publication/311101048, diakses 21 Desember 2018).

World Bank. 2011. World Development Report 2012: Gender Equality and Development. Washington, DC: World Bank. 